\title{
Use of the Computer and Internet by Teachers in Medical Education: A Study at a Medical College of North India
}

\author{
Satish C. Agrawal $^{1}$, Anita Kumari ${ }^{1}$
}

\begin{abstract}
Background: The computer and internet are used widely by the education community. A number of studies carried out in different parts of the world including India, have clearly shown that medical students use this technology freely and frequently. However, the situation with regard to medical teachers is not very clear as little information is available. The present study was conducted to determine the extent of the use of computers and internet by teachers in medical education.
\end{abstract}

Methods: A questionnaire based study was conducted among all available teachers working at S.R.M.S. Institute of Medical Sciences, Bareilly (U.P.), India between March and June, 2012. Total of 142 medical teachers participated.

Results and Conclusion: The majority (83.09\%) use computers and internet for teaching. These teachers use computers for PowerPoint presentations while teaching, a vast majority of them $(88.13 \%)$ use the internet to prepare their teaching materials. A significant statistical correlation was observed between computer and internet use and the younger age of teachers $(p<0.001)$. Similarly, a significant correlation $(p<0.001)$ was noted with the rank of teachers; non-users are predominantly professors, while users belonged to lower ranks (assistant professor or associate professor).

Keywords: computer, internet, teachers, medical education

\section{Introduction}

The history of the wonder machine 'computer' is long, the first personal computer (PC) introduced was in 1975 by Ed Roberts. The first portable computer 'IBM 5100', weighed 55 pounds and had a 5 inch display and was released the same year. However, the first truly portable laptop was marketed 1981 (Anon n.d.), and the size and weight decreased with time. The use of computers by the public and the educational community increased, and the use of the internet also expanded.

\footnotetext{
${ }^{1}$ Associate Professor,

Department of Pediatrics,

S.R.M.S. Institute of Medical Sciences, India

Corresponding author:

Dr Satish C. Agrawal

Department of Pediatrics,

S.R.M.S. Institute of Medical Sciences

Bareilly (U.P.) 243 202, INDIA
}

Email : satishagrawal1947@yahoo.com
ARPAnet was the original internet. It brought the internet in 1969 under a contract let by Advanced Research Projects Agency (ARPA) which initially connected four major computers at different universities (Bellis \& May, n.d.). However, networking became increasingly common since 1973, when Robert Metcalfe and Xerox started the 'Ethernet Computer Networking' (Howe \& Walt, n.d.). Use of the internet opened new vistas which accessed knowledge worldwide. The need and importance of the postal department and the library decreased. The last decade saw a revolution in the way internet could be accessed with the advent of the tablet, palmtop and smart phone.

Over the decades, not only the general public experience, but scientific evidence has shown that the use of information technology has significantly increased. Use of information technology by medical professionals has increased and has brought improvement in medical care. As far as use of computer or information technology in medical education is concerned, medical students are regular users 
of computer and internet (Inamdar \& Rotti, 2004; Sharma et al., 2006; Lal et al, 2006; Banerjee et al., 2011). Handheld computers are useful in medical education and patient care (Kho et al., 2006). However, there is paucity of literature regarding the use of computers and internet by teachers in medical education, which has led us to undertake the present study. The present study endeavours to determine the use of computers and internet by medical teachers and factors associated with their use.

\section{Methods}

The study was carried out among teaching faculty members of all the departments of the SRMS Institute of Medical Sciences, a private medical college, recognized by the Medical Council of India for undergraduate and postgraduate medical education. The faculty members in the study are involved in formal classroom teaching, i.e., assistant professors, associate professors and professors. Tutors, demonstrators and residents were not included in the study. Although $100 \%$ of the teaching faculty were targeted, there were a few non respondents. A total of 142 teachers participated.

The study was conducted with the approval of the scientific and ethical committee of the Institute. Data was obtained using a questionnaire. The questionnaire, besides containing the basic information, e.g., age, sex, designation, department and experience as a medical teacher, contained questions pertaining to the use of computers and internet, in teaching and the other relevant questions. It was pretested on a small random group of teachers, and on the basis of their response minor modifications were made and some of questions were deleted. Each teacher was individually interviewed.

For the purpose of the study the departments were divided in 3 groups, viz., pre-clinical (comprising the departments of Anatomy, Physiology, Biochemistry, Pharmacology and Forensic Medicine), para-clinical (departments of Pathology, Microbiology, Community Medicine, Radiodiagnosis and Anesthesiology) and clinical (departments of Medicine, General Surgery, Obstetrics \& Gynecology, Pediatrics, Orthopedics, Ophthalmology, E.N.T., Psychiatry, Dermatology, Pulmonary Medicine and Radiotherapy). Respondents were grouped under 3 categories on the basis of age i.e., up to 40 years (assuming every teacher is at least 25 years old), between 41 and 55 years and those above 55 years (up to 70 years, maximum).

The data was analyzed by using SPSS (Statistical Package for Social Sciences), applying Chi square test; a $p$ value $<0.05$ was considered statistically significant.

\section{Results}

The base line data of the teachers participating in the study are depicted in Table 1 , which clearly shows a preponderance of males belonging to the younger age group; the interesting finding is the older age group teachers being higher in number than the middle age group.

Table 1: Baseline data of the study population (total no 142)

\begin{tabular}{clcc}
\hline \multicolumn{1}{c}{ S. No. } & \multicolumn{1}{c}{ Characteristic } & Number & Percentage \\
\hline 1. & Age group (age in years) & & \\
(i) & Up to 40 & 90 & 63.38 \\
(ii) & $41-55$ & 13 & 9.15 \\
(iii) & $>55$ & 39 & 27.46 \\
2. & Sex & & \\
(i) & Male & 103 & 72.53 \\
(ii) & Female & 39 & 27.46 \\
& & & \\
3. & Department category & & \\
(i) & Preclinical & 23 & 16.19 \\
(ii) & Paraclinical & 30 & 21.12 \\
(iii) & Clinical & 89 & 62.67 \\
4. & Rank of teachers & & \\
(i) & Assistant Professor & 76 & 53.52 \\
(ii) & Associate Professor & 37 & 26.05 \\
(iii) & Professor & 29 & 20.42 \\
\hline
\end{tabular}


Table 2 shows distribution of all the study subjects according to the use of computers and internet, especially for teaching purpose. The table also shows the number of those who do not use computers and also the reasons thereof. Table 3 describes how teachers use computers in teaching; they use power point presentation for classroom teaching, most depend solely on it, while other teacher's mix it with the traditional method (blackboard). Use of internet for collection of teaching material is done by most, but not all. Table 4 shows distribution of those using and not using computers, for teaching based on their age, sex, department category (pre-clinical, paraclinical or clinical) and the teacher's academic position (assistant professor, associate professor or professor) to find a correlation between the computer use and other factors.

Table 2: Distribution according to the use of computer and internet (n 142)

\begin{tabular}{rcc}
\hline \multicolumn{1}{c}{ Category } & No of teachers & Percentage \\
\hline 1. Not using computers at all & $\mathbf{1 8}$ & $\mathbf{1 2 . 6 7}$ \\
(i) $\quad$ Never felt the need, so never tried & 5 & 3.52 \\
(ii) $\quad$ Appears very complicated & 6 & 4.22 \\
(iii) $\quad$ Tried but could not learn & 7 & 4.92 \\
2. Using computers & 124 & $\mathbf{8 7 . 3 2}$ \\
(i) $\quad$ Using computers but not for teaching & 6 & 4.22 \\
(ii) $\quad$ Using computer for teaching purpose & 118 & 83.09 \\
\hline
\end{tabular}

Table 3: Pattern of use by those using computers for teaching (n 118)

\begin{tabular}{llrl}
\hline S. N. & \multicolumn{1}{c}{ Characteristic } & No & Percentage \\
\hline 1. & No of teaching through PowerPoint presentation & $\mathbf{1 1 8}$ & $\mathbf{1 0 0}$ \\
(i) & Teaching mostly through slides & 92 & 77.96 \\
(ii) & Using slides along with traditional way of teaching & 26 & 22.03 \\
& & 104 & $\mathbf{8 8 . 1 3}$ \\
2. & $\begin{array}{l}\text { No of those using internet for collection of material for } \\
\text { teaching }\end{array}$ & & \\
\hline
\end{tabular}

Table 4: Distribution pattern of all the study subjects - those using computer and those not using computer for teaching purpose (n 142)

\begin{tabular}{|c|c|c|c|c|c|}
\hline & Characteristic & Total No & $\begin{array}{c}\text { No of users } \\
(n=118)\end{array}$ & $\begin{array}{c}\text { No of non-users } \\
(n=24)\end{array}$ & $p$ value \\
\hline $\begin{array}{l}1 . \\
\text { (i) } \\
\text { (ii) } \\
\text { (iii) }\end{array}$ & $\begin{array}{l}\text { Age group } \\
\text { Up to } 40 \text { years } \\
41-55 \text { years } \\
\text { Above } 55 \text { years }\end{array}$ & $\begin{array}{l}90 \\
13 \\
39\end{array}$ & $\begin{array}{l}86(72.88 \%) \\
12(10.16 \%) \\
20(16.94 \%)\end{array}$ & $\begin{array}{r}4(16.66 \%) \\
1(04.16 \%) \\
19(79.16 \%)\end{array}$ & $<0.001$ \\
\hline $\begin{array}{l}2 . \\
\text { (i) } \\
\text { (ii) }\end{array}$ & $\begin{array}{l}\text { Sex } \\
\text { Male } \\
\text { Female }\end{array}$ & $\begin{array}{c}103 \\
39\end{array}$ & $\begin{array}{l}82(69.49 \%) \\
36(30.54 \%)\end{array}$ & $\begin{array}{r}20(83.33 \%) \\
4(16.66 \%)\end{array}$ & 0.169 \\
\hline $\begin{array}{l}3 . \\
\text { (i) } \\
\text { (ii) } \\
\text { (iii) }\end{array}$ & $\begin{array}{l}\text { Department category } \\
\text { Pre-clinical } \\
\text { Para-clinical } \\
\text { Clinical }\end{array}$ & $\begin{array}{l}23 \\
30 \\
89\end{array}$ & $\begin{array}{l}20(16.94 \%) \\
26(22.03 \%) \\
72(61.01 \%)\end{array}$ & $\begin{array}{r}5(20.83 \%) \\
3(12.50 \%) \\
16(66.66 \%)\end{array}$ & 0.560 \\
\hline $\begin{array}{l}4 . \\
\text { (i) } \\
\text { (ii) } \\
\text { (iii) }\end{array}$ & $\begin{array}{l}\text { Rank of teachers } \\
\text { Assistant Professor } \\
\text { Associate Professor } \\
\text { Professor }\end{array}$ & $\begin{array}{l}76 \\
37 \\
29\end{array}$ & $\begin{array}{l}67(63.15 \%) \\
34(30.74 \%) \\
17(14.12 \%)\end{array}$ & $\begin{array}{r}3(12.50 \%) \\
1(04.16 \%) \\
20(83.33 \%)\end{array}$ & $<0.001$ \\
\hline
\end{tabular}




\section{Discussion}

The computer and internet are increasingly being used by the younger generation, including medical students. A number of studies have been conducted to find the extent of the use of computers and internet among medical students all of which substantiate the general impression that they are being used to a significant extent (Inamdar \& Rotti, 2004; Sharma et al., 2006; Lal et al., 2006; Banerjee et al., 2011; Kho et al., 2006). However, the same cannot be said about medical teachers. Although, Devitt and Palmer (2001) commented more than a decade ago, 'It is possible that suitably prepared computerized materials will be used to replace traditional styles of teaching, namely the lecture, tutorial and practical class', to what extent it has really happened is still not clear. The present study is an endeavour in this direction.

It is significant that the participants of the study are unevenly distributed between different age groups, with very few belonging to the middle age group (9.72\% only). The institution being relatively new, has a high number of young faculty members. Many teachers retired from their respective services choose to join a private medical college, where they can continue to work till the age of 70 . Obviously, these teachers have increased the upper age group. There is an imbalance between the numbers belonging to the pre-clinical, paraclinical and clinical departments, due to a higher number of clinical departments.

Table 2, confirms that a majority of the teachers use computers. Reasons for non use by the minority $(12.67 \%)$ are; some teachers do not feel the need to use a computer and inability to learn in spite of trying. Among those who are computer users, a small group uses the computer only for personal use. Further analysis has been done of both groups, i.e., the group comprising 118 teachers, using computers for teaching purpose as well as of the one having 24 teachers, who do not use them for teaching.

Analysis of use of computers and internet in teaching revealed that most teachers use PowerPoint presentations and the internet (either fully or partially) while $11.87 \%$ of teachers do not (Table 3).

Table 4 depicts correlation with age, sex, departmental category or teachers' academic position. While we could not find any significant correlation with sex and the department category, a significant statistical correlation ( $p$ value $<0.001$ ) was found with age; most users belong to the younger age group, while most non-users are of the older age. Similarly, a significant correlation was noted with the rank of teachers; non-users are predominantly professors. This is expected as the academic position generally parallels age.

We compared our observations with other studies but could not find a similar study. A study by Renwick (2005) from the West Indies focused on library sciences.

Computer users, including those who use it for teaching, use the computer for various personal uses, for writing letters and storing music, photographs, videos and documents including financial documents, and playing games. The internet is used for sending and receiving emails, downloading music, videos and films, making financial transactions, buying articles online, accessing information of various types and also for telephone calling, through services such as Skype. A significant number of respondents also use it for socializing through social media services like Facebook and Twitter. It was revealed that almost all (except those who do not know or use the computer at all) have their own personal computers and very few have to depend on the services of the library or department computers; most have their own laptops, many have more than one - a laptop as well as a desktop at home. An interesting finding was that several faculty members, mostly the younger ones have smart mobile phones (in addition to laptops) with which they frequently access the net with ease. The usual internet sites accessed for information on medical subjects were e.g., Emedicine/ Medscape, Medline, Pubmed; yet the most popular search engine for medical information was Google.

Teachers participating in the study using computers and the internet found it convenient, readily available, economical and gave them access to the most recent knowledge without having to consult many books and journals. An opinion was also sought from medical teachers regarding the desirability of including computer education in the medical curriculum at the undergraduate level and an overwhelming majority was in favour. However, these issues may be the subject for a separate study.

A limitation of the present study was that it was limited to the teachers of a single medical 
college. Results could have been more useful and better validated, had it included several medical colleges from different regions. Secondly, the study would have proved more useful if it had feedback from students.

\section{Conclusion}

A vast majority of teachers of SRMS Institute of Medical Sciences, Bareilly, India use computers and internet for medical education. This use is more frequently seen among the teachers of younger age, and in assistant professors and associate professors. Conversely, most of the teachers not using computers and internet for teaching are older in age, mostly professors.

\section{Acknowledgements}

The authors are thankful to the management of SRMS Institute of Medical Sciences, Bareilly for permission to conduct this study. We are also thank all the faculty members for their wholehearted support and cooperation.

\section{References}

Anonymous., (n.d.) When was the first computer invented? Available at www.computerhope.com/ issues/ch000984.htm [Accessed on Aug 25, 2012].

Banerjee, I., Biswas, S., Biswas, A. De. M., Begum, S.A. \& Haldar, S. (2011). Trends to access internet among medical students of a government medical college in West Bengal. Journal of the Indian Medical Association, 109, pp. 459-461.
Bellis \& Mary, (n.d.) The History of Computers. Available at: inventors.about.com/library /blcoindex.htm [Accessed on Aug 25, 2012].

Devitt, P. \& Palmer, E. (2001) The role of computers in medical education, Rev Cubana Educ Med Super, 15, 1, pp.76-84.

Howe \& Walt. (n.d.) A Brief History of the Internet. Available at walthowe.com/navnet/history.html [Accessed on Sep 14, 2012].

Inamdar, S.C. \& Rotti, S.B. (2004) Computer use among medical students in an institution in southern India, National Medical Journal of India, 17, pp.8-10.

Kho, A., Henderson, L.E., Dressler, D.D. \& Kripalani, S. (2006) Use of handheld computers in medical education: A systemic review, Journal of General Internal Medicine, 21, 5, pp. 531-537.

Lal, P. Malhotra, R., Ahuja, C. \& Ingle, G.K. (2006). Internet use among medical students and residents of a Medical College of North India. Indian Journal of Community Medicine, 31, pp. 293-294.

Renwick, S. (2005) Knowledge and use of electronic information resources by medical sciences faculty of the University of the West Indies, Journal of the Medical Library Association, 93, 1, pp. 21-31.

Sharma, R., Verma, U., Sawney, V., Arora, S. \& Kapoor, V. (2006). Trend of internet use among medical students, JK Science, 8, pp. 101-102.

Unnikrishnan, B., Kulshrestha, Saraf, A., Agrahari, A.C., Prakash, S. \& Samantaray, L. et al., (2008). Pattern of computer and internet use among medical students in Coastal South India. South East Asian Journal of Medical Education, 2, 2, pp. 18-25. 